\title{
ASPEK HUKUM PENGATURAN TATA RUANG TERHADAP ALIH FUNGSI LAHAN DALAM RANGKA PEMBANGUNAN NASIONAL
}

\author{
Oleh: Nabbilah Amir, S.H., M.H. \\ Dosen Fakultas Hukum Universitas Surabaya \\ Email: nabila.amir@staff.ubaya.ac.id
}

\begin{abstract}
Abstrak
Pengalihan lahan ke pembangunan berkelanjutan diarahkan pada perencanaan jangka panjang, berkelanjutan. Perencanaan pembangunan berkelanjutan memerlukan pendekatan simultan antara tiga dimensi utama pembangunan berkelanjutan: (1). Kelestarian lingkungan dapat terjadi jika dalam semua aktivitasnya, manusia tetap berpendapat bahwa pemanfaatan sumber daya alam masih berada di bawah daya dukung lingkungan dan limbah yang dihasilkan dari pemanfaatan sumber daya alam juga masih di bawah ambang batas. (2). Keberlanjutan pertumbuhan ekonomi dilakukan dengan mempertahankan modal (sumber daya alam) atau menjaga agar modal tidak turun saat modal digunakan. (3). Keberlanjutan sistem sosial yang menekankan aspek kualitas daripada aspek pertumbuhan kuantitas.
\end{abstract}

Kata kunci: Aspek Hukum, Peraturan tentang Alih Fungsi Lahan dan Pengembangan

\begin{abstract}
The transfer of land to sustainable development is directed toward long-term, longterm planning. Sustainable development planning requires a simultaneous approach between three key dimensions of sustainable development: (1). Environmental sustainability can occur if in all its activities, humans maintain that the utilization of natural resources is still under the carrying capacity of the environment and the waste generated from the utilization of natural resources is also still below the threshold. (2). The sustainability of economic growth is done by maintaining capital (natural resources) or keeping capital from declining when capital is utilized. (3). Sustainability of social system that emphasizes quality aspect rather than quantity growth aspect.
\end{abstract}

Keywords: Legal Aspect, Regulation On Land Function and Development Framework 


\section{Latar Belakang Masalah}

Negara Indonesia adalah negara kepulauan yang memiliki pulau terbentang dari Sabang sampai Merauke. Negara Indonesia juga merupakan negara yang memiliki jumlah penduduk sangat besar yakni 257.912.349 jiwa ${ }^{1}$. Jumlah penduduk tersebut semakin bertambah setiap tahunnya. Dengan melihat kondisi yang demikian, maka Indonesia rentan akan terjadinya alih fungsi lahan untuk dijadikan bangunan sebagai tempat berkoloni dimana lahan produktif dijadikan perumahan untuk menunjang pertambahan penduduk. Seiring perkembangan zaman dan dinamika gerak langkah pembangunan serta pertumbuhan jumlah penduduk, eksistensi lahan mulai terusik. Salah satu permasalahan yang cukup terkait dengan makin maraknya alih fungsi lahan pertanian kepenggunaan lainnyan seperti pembangunan pemukiman penduduk, industri, pertokoan, dan pariwisata, sehingga hal ini dapat memicu terjadinya alih fungsi lahan.

Alih fungsi lahan atau lazimnya disebut sebagai konversi lahan adalah perubahan fungsi sebagian atau seluruh kawasan lahan dari fungsinya semula menjadi fungsi lain yang membawa dampak negatif terhadap lingkungan dan potensi lahan itu sendiri. Alih fungsi lahan juga dapat diartikan sebagai perubahan untuk penggunaan lain disebabkan oleh faktor-faktor yang secara garis besar meliputi keperluan untuk memenuhi kebutuhan penduduk yang makin bertambah jumlahnya dan meningkatnya tuntutan akan mutu kehidupan yang lebih baik. ${ }^{2}$ Alih fungsi lahan biasanya terkait dengan proses perkembangan wilayah, bahkan dapat dikatakan bahwa alih fungsi lahan merupakan konsekuensi dari perkembangan wilayah. Sebagian besar alih fungsi lahan yang terjadi, menunjukkan adanya ketimpangan dalam penguasaan

\footnotetext{
${ }^{1}$ https://www.bps.go.id/index.php/pencarian?searching=jumlah+peduduk+indonesia+2016\&yt $\underline{1=\text { Cari. }}$. Diakses pada 7 Juni 2017

${ }^{2}$ https://agribisnis14.wordpress.com/.../alih-fungsi-lahan-pertanian/. Di akses pada tanggal 7 Juni 2017
} 
lahan yang lebih didominasi oleh pihak kapitalis dengan mengantongi izin mendirikan bangunan yang dikeluarkan oleh pemerintah.

Alih fungsi lahan pada hakekatnya merupakan hal yang wajar terjadi pada era modern seperti sekarang ini, namun alih fungsi lahan pada kenyataannya membawa banyak masalah karena terjadi diatas lahan yang masih produktif. Lahan pertanian dapat memberikan banyak manfaat seperti dari segi ekonomi, sosial, dan lingkungan. Namun, jika alih fungsi lahan pertanian produktif dibiarkan saja dan tidak dikendalikan maka sudah tentu akan berdampak negatif bagi masyarakat itu sendiri, mengingat begitu penting dan bermanfaatnya lahan pertanian bagi masyarakat. ${ }^{3}$

Selanjutnya, ruang wilayah Negara Kesatuan Republik Indonesia, baik sebagai kesatuan wadah yang meliputi ruang darat, ruang laut, dan ruang udara, termasuk ruang di dalam bumi maupun sebagai sumber daya, merupakan karunia Tuhan Yang Maha Esa kepada bangsa Indonesia yang perlu disyukuri, dilindungi dan dikelola secara berkelanjutan untuk sebesar-besarnya kemakmuran rakyat sebagaimana diamanatkan dalam Pasal 33 Ayat (3) Undang-Undang Dasar Negara Republik Indonesia Tahun 1945 (UUDNRI 1945) yang menegaskan bahwa "Bumi dan air dan kekayaan alam yang terkandung didalamnya dikuasai oleh negara dan dipergunakan untuk sebesarbesarnya kemakmuran rakyat". Untuk mewujudkan amanat tersebut maka dibentuklah Undang-Undang tentang Penataan Ruang, yang pelaksanaan wewenangnya dilakukan oleh Pemerintah pusat dan daerah dengan tetap menghormati hak yang dimiliki oleh setiap orang.

Kebijakan penataan Tata Ruang diatur melalui Undang-Undang Nomor 26 Tahun 2007 tentang Penataan Ruang. Dengan lahirnya Undang-Undang Penataan Ruang dengan turunannya berupa rencana tata ruang merupakan upaya penting dalam menertibkan penyelenggaraan penataan ruang di Indonesia yang diwujudkan melalui beberapa aspek penting, salah satu diantaranya pengendalian pemanfaatan ruang. Pengendalian pemanfaatan ruang dilaksanakan secara sistematik melalui penetapan

\section{${ }^{3}$ Ibid}


peraturan zonasi, perizinan, pemberian insentif dan disinsentif, serta sanksi. Kegiatan penataan ruang terdiri dari 3 (tiga) kegiatan yang saling terkait, yaitu: perencanaan tata ruang, pemanfaatan ruang, dan pengendalian pemanfaatan ruang, dengan produk rencana tata ruang berupa Rencana Tata Ruang Wilayah (RTRW) yang secara hirarki terdiri dari Rencana Tata Ruang Wilayah Nasional (RTRWN), Rencana Tata Ruang Wilayah Provinsi (RTRWP), dan Rencana Tata Ruang Wilayah Kabupaten/Kota (RTRW Kab/kota). ${ }^{4}$

Ketiga rencana tata ruang tersebut harus dapat terangkum di dalam suatu rencana pembangunan sebagai acuan di dalam implementasi perencanaan pembangunan berkelanjutan di wilayah Indonesia. Sebagai payung hukum dalam penyelenggaraan penataan ruang, maka Undang-Undang Penataan Ruang ini diharapkan dapat mewujudkan rencana tata ruang yang dapat mengoptimalisasikan dan memadukan berbagai kegiatan sektor pembangunan, baik dalam pemanfaatan sumberdaya alam maupun sumberdaya buatan yang berupa bangunan gedung, hotel apartemen dan lain sebagainya. ${ }^{5}$

Dengan terbatasnya lahan yang tersedia dan guna mewujudkan cita cita yang terkandung dalam Pasal 33 ayat (3) UUD 1945 maka perlu dilakukan penataan ruang, sebagaimana tercantum dalam Pasal 3 Undang-Undang Penataan Ruang (UUPR), dimana penyelenggaran Penataan Ruang bertujuan untuk mewujudkan ruang wilayah nasional yang aman, nyaman, produktif, dan berkelanjutan berlandaskan Wawasan Nusantara dan Ketahanan Nasional dengan:

1. Terwujudnya keharmonisan antara lingkungan alam dan lingkungan buatan

2. Terwujudnya keterpaduan dalam penggunaan sumber daya alam dan sumber daya buatan dengan memperhatikan sumber daya manusia; dan

4 Badan Pembinaan Hukum Nasional Kementerian Hukum dan Hak Asasi Manusia R.I., Laporan Akhir Tim Pengkajian Hukum Tentang Penegakan Hukum Penataan Ruang Dalam Kerangka Otonomo Daerah, Jakarta, 2014, h. 1

${ }^{5}$ Badan Pembinaan Hukum NasionalKementerian Hukum dan Hak Asasi Manusia, Op.Cit, h. 2 
3. Terwujudnya pelindungan fungsi ruang dan pencegahan dampak negatif terhadap lingkungan akibat pemanfaatan ruang.

Karena disadari bahwa bila pemanfaatan ruang tidak diatur dengan baik, kemungkinan besar akan terdapat pemborosan manfaat ruang dan penurunan kualitas ruang. Oleh karena itu, diperlukan penataan ruang untuk mengatur pemanfaatannya berdasarkan besaran kegiatan, jenis kegiatan, fungsi lokasi, kualitas ruang dan estetika lingkungan. ${ }^{6}$

Bangunan gedung sebagai tempat manusia melakukan kegiatannya, mempunyai peranan yang sangat strategis dalam pembentukan watak, perwujudan produktivitas, dan jati diri manusia. Oleh karena itu, penyelenggaraan bangunan gedung perlu diatur dan dibina demi kelangsungan dan peningkatan kehidupan serta penghidupan masyarakat, sekaligus untuk mewujudkan bangunan gedung yang fungsional, handal, berjati diri, serta seimbang, serasi, dan selaras dengan lingkungannya.

Dewasa ini bangunan gedung di Indonesia telah diatur dalam dasar hukum yang kuat, yaitu dalam bentuk undang-undang yang memiliki aturan pelaksanaan berupa peraturan pemerintah. Undang-undang dimaksud adalah Undang-Undang Nomor 28 Tahun 2002 tentang Bangunan Gedung yang diundangkan dan mulai berlaku pada tanggal 16 Desember 2002. Sebagai aturan pelaksanaannya pemerintah telah menerbitkan Peraturan Pemerintah Nomor 36 Tahun 2005 Tentang Bangunan Gedung, yang ditetapkan dan mulai berlaku pada tanggal 10 September 2005.

Bangunan gedung merupakan salah satu wujud fisik pemanfaatan ruang. Oleh karena itu dalam pengaturan bangunan gedung tetap mengacu pada pengaturan penataan ruang sesuai peraturan perundang-undangan yang berlaku. Untuk menjamin kepastian dan ketertiban hukum dalam penyelenggaraan bangunan gedung, setiap

\footnotetext{
${ }^{6}$ Ketentuanl tersebut tercantum dalam Pasal 14 dan Pasal 15 Undang-Undang Nomor 5 Tahun 1960 (UUPA) Tentang Peraturan Dasar Pokok-Pokok Agraria, dimana perencanaan perlu dilakukan agar bumi (tanah), air dan ruang angkasa dapat memberikan manfaat sebesar-besarnya bagi negara dan rakyat.
} 
bangunan gedung harus memenuhi persyaratan administratif dan teknis bangunan gedung, serta harus diselenggarakan secara tertib.

Alokasi ruang dalam kegiatan penataan ruang tidak hanya menata berbagai kegiatan pembangunan secara spasial yang dikaitkan dengan kesesuaian lahan saja, tapi juga memperhitungkan dan mempertimbangkan dampak yang terjadi akibat pembangunan terhadap lingkungan agar dampak negatif dapat dihindari dalam rangka tercapainya tujuan pembangunan yang berkelanjutan. Internalisasi aspek lingkungan ke dalam penataan ruang diharapkan dapat menjadi acuan terwujudnya esensi dasar pembangunan berkelanjutan.

Peran pengendalian pemanfaatan ruang sesungguhnya menjadi amat penting dan menjadi ujung tombak dalam upaya penataan ruang ke depan. Tugas penataan ruang bersifat strategis dan kegiatannya melibatkan berbagai stakeholder sehingga penanganannya di daerah perlu dilakukan secara koordinatif dengan mempertimbangkan berbagai kepentingan pemerintah dan masyarakat.

\section{Rumusan Masalah}

Dari uraian latar belakang di atas, maka isu hukum yang dapat ditarik dalam penelitian ini adalah sebagai berikut:

a. Penataan ruang terhadap alih fungsi lahan

b. Alih Fungsi Lahan terhadap Pembangunan Berkelanjutan

\section{Metode Penelitian}

Mengingat ini merupakan penelitian hukum normatif, sehingga metode yang digunakan adalah metode penelitian hukum yang dilakukan untuk mencari pemecahan masalah atas isu hukum dan permasalahan hukum yang ada, sehingga hasil dari penelitian hukum ini adalah memberikan preskripsi mengenai apa yang 
seyogyanya mengenai isu hukum yang diajukan serta dapat diterapkan dalam praktek hukum pemerintahan.

\section{Pendekatan Penelitian}

Pendekatan yang digunakan dalam penelitian hukum normatif adalah pendekatan perundang-undangan (statute approach) dan pendekatan konseptual (conceptual approach). ${ }^{7}$

Pendekatan perundang-undangan (statuteapproach) diperlukan guna mengkaji lebih lanjut mengenai aspek hukum pengaturan penataan ruang terhadap alih fungsi lahan dalam rangka pembangunan nasional. Pendekatankonseptual (conceptual approach), digunakan untuk mengkaji dan menganalisis kerangka pikir atau kerangka konseptual maupun landasan teoritis sesuai dengan tujuan penelitian ini yakni menjelaskan aspek hukum pengaturan penataan ruang terhadap alih fungsi lahan dalam rangka pembangunan nasional. Oleh karena itu perlu dikemukakan tentang teori penataan ruang dan alih fungsi lahan serta teori-teori lainnya yang relevan.

\section{Sumber Bahan Hukum}

Bahan-bahan penelitian berupa bahan hukum primer dan bahan hukum sekunder. Bahan Hukum Primer yang digunakan dalam Penelitian ini antara lain Undang-Undang Dasar Negara Republik Indonesia Tahun 1945; Undang-Undang Nomor 5 Tahun 1960 Tentang Peraturan Dasar Pokok-Pokok Agraria; UndangUndang Nomor 28 Tahun 2002 tentang Bangunan Gedung; Undang-Undang Nomor 26 Tahun 2007 tentang Penataan Ruang dan Peraturan Pemerintah Nomor 36 Tahun 2005 Tentang Bangunan Gedung.

Bahan hukum sekunder meliputi bahan-bahan yang mendukung bahan hukum primer seperti buku-buku teks khusunya buku-buku tentang hukum pemerintahan,

${ }^{7}$ Peter Mahmud Marzuki, Penelitian Hukum, Cet. 6,Kencana Prenada Media Group, Jakarta, 2010, hal. 35 
buku-buku tentang Otonomi Daerah, kamus hukum, artikel dalam berbagai majalah dan jurnal ilmiah bidang hukum, dan sumber lainnya yang mendukung.

\section{Hasil Penelitian dan Pembahasan}

\section{Penataan Ruang Terhadap Alih Fungsi Lahan}

Dalam upaya mencapai tujuan nasional, dilakukanlah kegiatan pembangunan nasional sebagai rangkaian upaya pembangunan yang berkesinambungan yang meliputi seluruh aspek kehidupan masyarakat, bangsa dan negara. ${ }^{8}$ Kegiatan tersebut memungkinkan terjadinya pemanfaatan lingkungan secara berlebihan sehingga mengakibatkan pencemaran dan perusakan lingkungan secara global. Untuk mengurangi dampak negative yang mungkin terjadi maka diperlukan perencanaan pembangunan yang baik. Produk perencanaan formal berdasarkan UU No. 24 tahun 1992 tentang penataan ruang dalam bentuk RUTRW yang dirinci lebih detail lagi dalam bentuk RDTR dan RRTR. ${ }^{9}$

Penataan Ruang adalah proses perencanaan tata ruang, pemanfaatan ruang dan pengendalian pemanfaatan ruang. ${ }^{10}$

Dalam kerangka Negara Kesatuan Republik Indonesia,penataan ruang diselenggarakan berdasarkan asas: ${ }^{11}$

1. keterpaduan;

2. keserasian, keselarasan, dan keseimbangan;

3. keberlanjutan;

4. keberdayagunaan dan keberhasilgunaan;

5. keterbukaan;

6. kebersamaan dan kemitraan;

${ }^{8}$ Ida Nurlinda, Prinsip- Prinsip Pembaruan Agraria "Perspektif Hukum", Jakarta:Rajawali Press 2009, h. 7.

${ }^{9}$ Ibid

${ }^{10}$ Ketentuan di atas merupakan bunyi Pasal 1 angka 5 Undang-Undang Nomor 26 tahun 2007 Tentang Penataan Ruang.

${ }^{11}$ Bunyi Pasal 2 Undang-Undang Nomor 26 tahun 2007 Tentang Penataan Ruang 
7. pelindungan kepentingan umum;

8. kepastian hukum dan keadilan; dan

9. akuntabilitas.

Berkaitan dengan alih fungsi lahan sendiri sebenarnya bukan merupakan persoalan yang baru. Alih fungsi lahan adalah perubahan fungsi sebagian atau seluruh kawasan lahan dari fungsinya semula menjadi fungsi lain. Banyak faktor yang mempengaruhi maraknya alih fungsi lahan salah satunya adalah kebijakan-kebijakan yang dikeluarkan oleh negara. Hal ini mulai terjadi sejak dikeluarkannya paket-paket kebijakan yang mendorong investor dalam dan luar negeri menanamkan modalnya di bidang non-pertanian sekitar pertengahan 1980-an. Keperluan lahan non-pertanian mengikuti trend peningkatan investasi tersebut. Keperluan lahan untuk bidang non-pertanian semakin meningkat pula seiring dengan booming pembangunan perumahan pada awal tahun 1990 -an. ${ }^{12}$

Saat ini misalnya di wilayah perkotaan alih fungsi lahan menjadi semakin meningkat seiring dengan maraknya pembangunan hotel, mall, maupun apartemen. Terjadinya perubahan penggunaan lahan dapat disebabkan karena adanya perubahan rencana tata ruang wilayah karena adanya kebijaksanaan arah pembangunan. Alih fungsi lahan saat ini tidak hanya terjadi di wilayah perkotaan. Namun, di pedesaan berubahnya fungsi lahan pertanian menjadi non-pertanian juga terjadi. Lahan pertanian yang berubah fungsi menjadi kawasan industri maupun disebabkan adanya pembangunanpembangunan yang didasarkan atas klaim kepentingan umum. ${ }^{13}$

Pertumbuhan penduduk yang sangat cepat di Indonesia, dengan dibarengi pertumbuhan ekonomi, dan dinamika sosial kehidupan, menyebabkan kebutuhan sarana dan prasarana semakin meningkat pula.

${ }^{12}$ https://agribisnis14.wordpress.com/.../alih-fungsi-lahan-pertanian/. Di akses pada tanggal 7 ${ }^{13}$ Ibid 
Berkenaan dengan pengamalan negara kesejahteraan (Welfare State) sesuai dalam negara Pancasila dan Undang-Undang Dasar Negara Republik Indonesia Tahun 1945, pemerintah berkewajiban untuk mengatur, menata dan menyelenggarakan pemenuhan kehidupan masyarakat sesuai batas kemampuannya. Bagi Indonesia, dengan lebih dari 17.000 pulau besar dan kecil, baik yang berpenghuni maupun yang tidak berpenghuni, sumber daya alam yang melimpah, hutan, gunung, sungai besar dan kecil, sumber daya hayati, baik di darat, laut maupun udara diatasnya, wajib dan telah diatur dalam berbagai peraturan perundang-undangan untuk kesejahteraan masyarakat, lahir dan batin.

Kemajuan ilmu pengetahuan dan teknologi yang sudah menjadi masalah global dalam melaksanakan pembangunan serta memenuhi kehidupan masyarakat, harus memperhatikan kepentingan kelestarian lingkungan dan daya dukung lingkungan, pemanfaatan yang proporsional diperlukan campur tangan pemerintah. Eksistensi dan kewenangan pemerintah untuk melakukan campur tangan dalam pengelolaan sumber daya dan yang menyangkut kehidupan orang banyak, bukan berarti monopoli yang bersifat mutlak. Namun partisipasi aktif dan pro aktif, serta proposionaldari warga masyarakat dengan memperhatikan kepentingan masyarakat yang lebih luas, generasi mendatang dan daya dukung lingkungan menjadi acuan yang harus di penuhi.

Sesuai prinsip Negara Kesatuan Republik Indonesia (NKRI), wilayah NKRI terdiri dari wilayah nasional (pusat), propinsi, Kota/Kabupaten, yang tetap dalam bingkai NKRI. Kepentingan kabupaten/kota dan propinsi dalam melaksanakan pembangunan sesuai era otonomi daerah, tetap harus selaras, sejalan dan mengacu pada kepentingan nasional. Dalam banyak hal, pembangunan secara makro, utamanya pembangunan ekonomi masyarakat berbagai aktifitas pembangunan, mulai pembangunan industri, pembangunan perumahan, transportasi, perdagangan, perkebunan, pertanian, kelautan/maritim dan lain-lain. Aktifitas dan penyelenggaraan pembangunan 
beraneka ragam tersebut sudah tentu memerlukan lahan yang sangat luas. Berkaitan tentang penyediaan lahan yang sangat luas, secara mendasar memerlukan ruang yang luas pula. Antara penyediaan lahan dan tata ruang yang luas, demi tercapainya kesejahteraan umum masyarakat, dengan sendirinya harus memperhatikan daya dukung lingkungan, serta merubah lingkungan yang lama menjadi lingkungan yang baru dalam segala aspek. ${ }^{14}$

Beberapa aspek yang baru, berkenaan pembangunan tata ruang, diantaranya masalah kepemilikan kemerosotan, bahkan kerusakan lingkungan pembenturan kepentingan berbagai kegiatan masyarakat baik disekitarnya maupun perpindahan penduduk yang semula menghuni kawasan tersebut, yang dapat menyebabkan timbulnya masalah sosial yang baru. Secara mikro berkenaan pertambahan penduduk yang tetap pesat, kebutuhan pada pemanfaatan ruang dan lahan semakin meningkat pula. Adapun ketersediaan lahan tetap seperti semula sehingga pemanfaatan lahan untuk memenuhi kebutuhan warga masyarakat semakin menjadi. Dalam hal perkembangan di kota besar, akibat urbanisasi penduduk yang sangat cepat dan masalah pembangunan ekonomi, bermunculan rumah-rumah bertingkat, apartemen, perkantoran, hotel-hotel dan sarana pendukung lainnya.

Dalam aspek pengelolaan pembangunan ekonomi di sektor perkebunan dan pertambangan di daerah Kabupaten/Kota dan Propinsi, alih fungsi hutan menjadi masalah baru. Pendapatan asli daerah (PAD), atau pajak-pajak lainnya dapat dinikmati oleh Kabupaten/Kota dan Propinsi namun kedamaian dan ketentraman masyarakat terkadang ada yang terabaikan. Daya dukung dan kerusakan lingkungan menjadi tambahan belum lagi tentang persoalan sengketa lahan. Dalam Rencana Pembangunan Jangka Panjang (RPJP) Nasional Tahun 2005-2025 diuraikan sebagai berikut: ${ }^{15}$

14 Badan Pembinaan Hukum Nasional Kementerian Hukum dan Hak Asasi Manusia R.I., Laporan Akhir Tim Pengkajian Hukum Tentang Penegakan Hukum............. Op.Cit., h. 30

${ }^{15}$ Ibid., h. 30 
1. Tata ruang Indonesia saat ini dalam kondisi krisis. Krisis tata ruang terjadi karena pembangunan yang dilakukan di suatu wilayah masih sering dilakukan tanpa mengikuti rencana tata ruang, tidak mempertimbangkan keberlanjutan dan daya dukung lingkungan serta tidak memperhatikan kerentanan wilayah terhadap terjadinya bencana alam. Keinginan untuk memperoleh keuntungan ekonomi jangka pendek seringkali menimbulkan keinginan untuk mengekspolitasi sumber daya alam secara berlebihan sehingga menurunkan kualitas dan kuantitas sumber daya alam dan lingkungan hidup, serta memperbesar resiko timbulnya korban akibat bencana alam. Selain itu sering terjadi konflik pemanfaatan ruang antar sektor, contohnya konflik antara kehutanan dan pertamabangan. Beberapa penyebab utamanya terjadinya permasalahan tersebut adalah (a) belum tepatnya kompetensi sumber daya manusia dalam bidang pengelolaan tata ruang, (b) rendahnya kualitas dari rencana tata ruang, (c) belum diacunya perundangan penaataan ruang sebagai payung kebijakan pemanfaatan ruang bagi semua sektor; dan (d) lemahnya penerapan hukum berkenaan dengan pemanfaatan ruang.

2. Pada umumnya masyarakat yang berada di wilayah tertinggal masih punya keterbatasan akses terhadap pelayanan sosial, ekonomi, dan politik serta terisolir dari wilayah sekitarnya. Oleh karena itu, kesejahteraan kelompok masyarakat yang hidup di wilayah tertinggal memerlukan perhatian dan keberpihakan pembangunan yang besar dari pemerintah. Permasalahan yang dihadapi dalam pengembangan wilayah tertinggal, termasuk yang masih dihuni oleh komunitas adat terpencil, antara lain, (1) terbatasnya akses informasi yang menghubungkan wilayah tertinggal dengan wilayah yang relatif maju; (2) kepadatan penduduk relatif rendah dan tersebar; (3) kebanyakan wilayah-wilayah tersebut miskin sumber daya, khususnya sumber daya alam dan manusia; (4) belum diprioritaskannya pembangunan di wilayah tertinggal oleh pemerintah daerah karena dianggap tidak 
menghasilkan pendapatan asli daerah (PAD) secara langsung; dan (5) belum optimalnya dukungan sektor terkait untuk pengembangan wilayahwilayah tersebut. ${ }^{16}$

3. Banyak wilayah yang memiliki produk unggulan; (2) belum adanya sikap profesionalisme dan kewirausahaan dari pelaku pengembangan kawasan di daerah; (3) belum optimalnya dukungan kebijakan nasional dan daerah yang berpihak pada petani dan pelaku usaha swasta; (4) belum berkembangnya infrastruktur kelambagaan yang berorientasi pada pengelolaan pengembangan usaha yang berkelanjutan dalam perekonomian daerah; (5) masih lemahnya koordinasi, sinergi, dan kerjasama diantara pelaku-pelaku pengembangan kawasan, baik pemerintah, swasta, lembaga non pemerintah, dan masyarakat serta antara pemerintah pusat, propinsi dan kabupaten/kota, dalam upaya meningkatkan daya saing produk unggulan; (6) masih terbatasnya akses petani dan pelaku usaha skala kecil terhadap modal pengembangan usaha, input produksi, dukungan teknologi, dan jaringan pemasaran, dalam upaya mengembangkan peluang usaha dan kerjasama investasi; (7) keterbatasan jaringan prasarana dan sarana fisik dan ekonomi dalam pengembangan kawasan dan produk unggulan daerah; serta (8) belum optimalnya pemanfaatan kerjasama antar wilayah untuk mendukung peningkatan daya saing kawasan dan produk unggulan.

4. Wilayah perbatasan, termasuk pulau-pulau kecil terluar memiliki potensi SDA yang cukup besar serta merupakan wilayah yang sangat strategis bagi pertahanan dan keamanan negara. Walaupun demikian, pembangunan di beberapa wilayah perbatasan masih sangat jauh tertinggal dibandingkan dengan pembangunan di wilayah negara tetangga. Kondisi soal ekonomi masyarakat yang tingggal di daerah tersebut umumnya jauh lebih rendah dibandingkan dengan kondisi sosial ekonomi warga negara tetangga. 
Permasalahan utama dari ketertinggalan pembangunan di wilayah perbatasan adalah arah kebijakan pembangunan kewilayahan yang selama ini cenderung berorientasi "inward looking" sehingga seolah-olah kawasan perbatasan hanya menjadi halaman belakang dari pembangunan negara. Akibatnya, wilayah-wilayah perbatasan dianggap bukan merupakan wilayah prioritas pembangunan oleh pemerintah pusat maupun daerah. Sementara itu, pulau-pulau kecil yang ada di Indonesia sulit berkembang terutama karena lokasinya sangat terisolasi dan sulit dijangkau, diantaranya banyak yang tidak berpenhuni atau sangat sedikit jumlah penduduknya serta belum banyak tersentuh oleh pelayanan dasar dari pemerintah.

5. Pertumbuhan kota-kota besar dan metropolitan saat ini masih sangat terpusat di pulau Jawa-Bali, sedangkan pertumbuhan kota-kota menengah dan kecil terutama di luar Jawa-Bali, sedangkan pertumbuhan kota-kota menengah dan kecil terutama di perkotaan banyak yang tidak seimbang ini ditambah dengan adanya kesenjangan pembangunan antar wilayah yang menimbulkan urbanisasi yang tidak terkendali. Secara fisik, hal itu ditunjukkan oleh (1) meluasnya wilayah perkotaan karena pesatnya perkembangan dan meluasnya kawasan pinggiran (fringe-area) terutama di kota-kota besar dan metropolitan; (2) meluasnya perkembangan fisik perkotaan di kawasan "sub urban" yang telah "mengintegrasi" kota-kota yang lebih kecil di sekitar kota inti dan membentuk konurbasi yang tak terkendali; (3) meningkatnya jumlah desa-kota; dan (4) terjadinya reklasifikasi (perubahan daerah rural menjadi daerah urban, terutama di Jawa). Kecendrungan perkembangan semacam itu berdampak negatif terhadap perkembangan kota-kota besar dan metropolitan itu sendiri maupun kota-kota menengah dan kecil di wilayah lain. ${ }^{17}$

\footnotetext{
${ }^{17}$ Ibid, h. 31 .
} 
6. Dampak negatif yang ditimbulkan dari kota-kota besar dan metropolitan, antara lain, adalah (1) terjadinya eksploitasi yang berlebihan terhadap sumber daya alam di sekitar kota-kota besar dan metropolitan untuk mendukung dan meningkatkan pertumbuhan ekonomi; (2) terjadinya secara terus menerus konversi lahan pertanian produktif menjadi kawasan pemukiman, perdagangan, dan industri; (3) menurunnya kualitas lingkungan fisik kawasan perkotaan akibat terjadinya perusakan lingkungan dan timbulnya polusi; (4) menurunnya kualitas hidup masyarakat di perkotaan karena permasalahan sosial-ekonomi, serta penurunan kualitas hidup masyarakat perkotaan; serta (5) tidak mandiri dan terarahnya pembangunan kota-kota baru sehingga justru menjadi tambahan beban bagi kota inti.

7. Kondisi sosial ekonomi masyarakat yang tinggal di pedesaan umumnya masih jauh tertinggal di bandingkan dengan yang tinggal di perkotaan. Hal itu merupakan konsekuensi dari perubahan struktur ekonomi dan proses industrialisasi, baik investasi ekonomi oleh swasta maupun pemerintah, sehingga infrastruktur dan kelembagaan cenderung terkonsentrasi di daerah perkotaan. Selain itu, kegiatan ekonomi di wilayah perkotaan masih banyak yang tidak sinergis dengan kegiatan ekonomi yang dikembangkan di wilayah pedesaan. Akibatnya peran kota yang diharapkan dapat mendorong perkembangan pedesaan justru memberikan dampak yang merugikan pertumbuhan pedesaan. ${ }^{18}$

Lebih lanjut, alih fungsi atau mutasi lahan secara umum menyangkut transformasi dalam pengalokasian sumber daya lahan dari suatu penggunaan ke penggunaan lainnya, sehingga proses konversi lahan ini melibatkan reorganisasi struktur fisik kota secara internal maupun ekspansinya kearah luar. Hal ini karena terdapat kaitan erat antara penggunaan lahan dan perubahan

\section{${ }^{18}$ Ibid}


demografis di kawasan perkotaan, yang dapat ditunjukkan dalam ukuran konsumsi lahan perkotaan.

Terdapat dua aspek yang mempengaruhi pemanfaatan lahan, yaitu $a$ spasial yang terdiri aspek perekonomian dan kependudukan; serta aspek spasial yang terdiri dari sistem aktifitas, sistem pengembangan dan sistem lingkungan. Perekonomian akan mempengaruhi perkembangan kegiatan ekonomi di kota seperti sektor industri, perdagangan dan jasa yang semuanya membutuhkan lahan. Pemanfaatan lahan tersebut umumnya diarahkan pada pola pemanfaatan yang efektif dan efisien, sehingga faktor lokasi menjadi cukup penting. Faktorfaktor yang mempengaruhi pergeseran spasial pemanfaatan lahan cukup bervariasi. Konsumsi terhadap lahan merupakan manifestasi dari kekuatan demografi dan ekonomi. Selain kedua kekuatan ini, sejumlah faktor lain juga memberikan pengaruhnya, yaitu perubahan penduduk, fungsi ekonomi yang dominan, ukuran wilayah, rata-rata nilai lahan, jumlah dan kepadatan penduduk, wilayah geografis dan kemampuan lahan. ${ }^{19}$

Ada tiga faktor eksternal yang mempengaruhi terjadinya konversi lahan, yaitu pertama, tingkat urbanisasi, situasi perekonomian masyarakat serta kebijakan dan program pembangunan daerah. Kedua, terdapat beberapa faktor eksternal yang mempengaruhi konversi lahan, yaitu laju pertumbuhan penduduk, kepadatan penduduk, laju pertumbuhan ekonomi, pertumbuhan kawasan terbangun dan kebijakan pemerintah. Ketiga, Aspek kependudukan juga mempengaruhi pemanfaatan lahan. Jumlah penduduk, kepadatan penduduk, dan pertumbuhan penduduk merupakan faktor-faktor yang dapat mempengaruhi pergeseran spasial lahan. ${ }^{20}$

19 Dwita Hadi Rahmi, Pengelolaan Sumberdaya dan Lingkungan, Gadjah Mada University Press, Yogyakarta, 2003, h. 11

${ }^{20}$ Sumardja, Effendy A., Pembangunan Berkelanjutan: Tantangan dan Peluang. Jurnal Lingkungan dan Pembangunan. 2004. 


\section{Alih Fungsi Lahan terhadap Pembangunan Berkelanjutan}

Maksud pembangunan berkelanjutan adalah untuk memastikan bahwa dengan upaya pembangunan, kesejahteraan generasi mendatang paling tidak akan mempunya potensi dan peluang ekonomi dan stok capital baik sumber daya alam, sumber daya manusia dan sumber daya buatan sama dengan peluang yang diperoleh generasi sekarang. Tantangan utama dalam pelaksanaan pembangunan berkelanjutan di Indonesia adalah belum sepenuhnya tercipta tata pemerintahan bersih, transparan, dapat dipertanggungjawabkan (accountable), representative dan demokratis.

Menurut Ida Nurlinda, ciri atau kriteria perencanaan pembangunan berkelanjutan berlandaskan kepada: ${ }^{21}$

1. Perencanaan yang berorientasi pada kepentingan jangka panjang.

2. Etika perencanaan pembangunan yang memikirkan pemenuhan kebutuhan generasi mendatang.

3. Pembatasan pendayagunaan sumberdaya yang tidak efisien, dan perubahan pola konsumsi.

4. Pemanfaatan alternatif sumberdaya energi yang dapat diperbaharui.

5. Pendistribusian kesempatan ekonomi secara merata.

Lebih lanjut lagi, Ida Nurlinda menjelaskan bahwa perencanaan pembangunan berkelanjutan memerlukan pendekatan yang bersifat simultan antara tiga dimensi pokok dari pembangunan berkelanjutan, yaitu: ${ }^{22}$

1. Keberlanjutan lingkungan dapat terjadi jika dalam segala aktivitasnya, manusia menjaga agar pemanfaatan sumberdaya alam masih di bawah daya dukung lingkungannya serta limbah yang dihasilkan dari pemanfaatan sumberdaya alam tersebut juga masih di bawah ambang batas.

\footnotetext{
${ }^{21}$ Ida Nurlinda, Prinsip- Prinsip Pembaruan Agraria........, .Op.Cit., h. 35

${ }^{22}$ Ibid., h. 36
} 
2. Keberlanjutan pertumbuhan ekonomi dilakukan dengan mempertahankan kapital (sumberdaya alam) atau menjaga agar kapital tidak mengalami kemerosotan ketika kapital tersebut dimanfaatkan.

3. Keberlanjutan sistem sosial yang menekankan pada segi kualitas daripada aspek pertumbuhan yang bersifat kuantitas. Keberlanjutan sistem sosial dapat dicapai apabila partisipasi masyarakat cukup tinggi serta dijalankan secara sistematis.

Disahkannya Undang-Undang No 26 Tahun 2007 tentang Penataan Ruang menyebabkan perlu diperbaharui Rencana Tata Ruang Nasional maupun Rencana Tata Ruang Wilayah, karena terdapat beberapa perbedaan tahapan perencanaan yang harus dilakukan. Klasifikasi penataan ruang berdasarkan Pasal 4 UUPR diklasifikasikan berdasarkan sistem, fungsi utama kawasan, wilayah administratif, kegiatan kawasan dan nilai strategis kawasan. Hal ini menunjukkan bahwa fungsi kawasan menjadi poin utama dalam merencanakan peruntukan lahan.

Urgensi pembaharuan aturan penataan ruang ini dilatarbelakangi oleh sifat dan karakteristik oleh sifat tanah yang merupakan sumber daya alam yang fungsi dan daya gunanya sangat penting bagi manusia. Pada dasarnya prinsip pemilikan atau penguasaan tanah oleh rakyat di suatu negara, terdiri dari dua prinsip yang berbeda: ${ }^{23}$

1. Di suatu negara agraris, dimana sebagian besar rakyat adalah pertanian sehingga mereka bergantung kepada tanah, untuk keadilan maka prinsipnya: tanah itu oleh negara dibagikan kepada sebanyak mungkin penduduk (dengan hak milik, hak guna bangunan, hak guna usaha), sehingga pemilikan/penguasaan tanah bagi tiap keluarga/pengusaha adalah terbatas/kecil.

${ }^{23}$ https://www.google.co.id/?hl=en\&gws $r d=s s l$ Hhl=en \& $q=i m p l i k a s i+$ pengaturan + penataan +ruang+terhadap+alih+fungsi+lahan. Di akses pada tanggal 9 Juni 2017 
2. Di suatu negara industri, dimana nafkah sebagian besar penduduk adalah industri maka hanya sedikit saja rakyat yang bertani atau yang bergantung kepada tanah, sehingga untuk memudahkan pengelolaan, prinsipnya: tanah itu oleh negara dibagikan kepada sebagian kecil dari penduduk, sehingga pemilikan/penguasaan tanah per keluarga/perusahaan dapat luas, ribuan atau puluhan ribu hektar bahkan ratusan ribu hektar. ${ }^{24}$

Dalam Strategi Nasional untuk Pembangunan Berkelanjutan yang dirumuskan Agenda 21 Nasional, Pengelolaan sumberdaya tanah terdiri dari 4 sub-agenda yaitu penatagunaan sumberdaya tanah, pengelolaan hutan, pengembangan pertanian dan pedesaan serta pengelolaan sumberdaya air. Pengaturan mengenai alih fungsi lahan masuk dalam sub agenda ini. Adapun alasan utama terjadinya alih fungsi lahan adalah laju pertumbuhan ekonomi dan pertambahan jumlah penduduk. ${ }^{25}$ Peralihan fungsi lahan dapat dilakukan oleh dua pihak yaitu pemerintah dan pemilik lahan. Alasan pemerintah melakukan alih fungsi lahan adalah perubahan RTRW dan kebutuhan akan infrastruktur, sedangkan alasan alih fungsi lahan yang dilakukan pemilik lahan adalah: ${ }^{26}$

1. Melihat kondisi lahan yang tidak bisa diharapkan untuk berproduksi optimal.

2. Harga tanah di sekitar lokasi meningkat pesat

3. Kebutuhan ekonomi yang tidak bisa dihindari

Alih fungsi lahan mengubah fungsi lahan yang ada. Perubahan fungsi lahan merupakan suatu keniscayaan, karena kebutuhan manusia akan lahan semakin lama semakin tinggi seiring dengan tingginya pertumbuhan manusia di Indonesia. Pengendalian alih fungsi lahan diperlukan agar generasi mendatang paling tidak mempunya potensi dan peluang ekonomi dan stok capital baik sumber daya alam, sumber daya manusia dan sumber daya buatan

\footnotetext{
24 Ibid

${ }^{25}$ Ibid, h. 15

${ }^{26}$ Ibid
} 
sama dengan peluang yang diperoleh generasi sekarang sebagaimana maksud dari pembangunan berkelanjutan. Strategi pengendalian ini harus memperhatikan alasan-alasan terjadinya alih fungsi lahan. Strategi tersebut mencakup peraturan kebijakan dan pelibatan masyarakat. Dalam peraturan kebijakan, strategi yang bisa dilakukan adalah: ${ }^{27}$

\section{Pengetatan Izin}

2. Pewilayahan (zooning) kawasan

3. Penyempurnaan sistem dan aturan jual beli lahan

4. Penyempurnaan pola penguasaan lahan (land tenure system)

5. Pemberian Subsidi

6. Pengurangan Pajak

Sedangkan strategi pelibatan masyarakat dilakukan dengan melakukan penyamaan persepsi, jalinan komitmen, keputusan kolektif, sinergi aktivitas penatagunaan tanah dengan pemerintah.

Perencanaan pembangunan dilaksanakan secara sektoral maupun dengan secara terpadu dalam satu wilayah. Proses pembangunan daerah yang digerakkan oleh pengembangan ekonomi daerah umumnya diawali dengan pengembangan pusat-pusat pertumbuhan baik yang bersifat lokal, dan berkembang ke skala regional maupun nasional dan internasional, melalui tahapan-tahapan yang dimulai dengan pusat pertumbuhan lokal, pengembangan klaster komoditas/industri sampai akhirnya terjadi proses aglomerasi di satu wilayah, yang selanjutnya memberikan efek pengganda bagi perkembangan daerah sekitarnya.

Sebagai bagian dari tahapan pengembangan tersebut, beberapa upaya pengembangan pusat-pusat pertumbuhan wilayah lokal dalam kerangka pengembangan keterkaitan desa-kota telah dilakukan, baik dengan membangun

\section{${ }^{27}$ Ibid}


pusat pertumbuhan lokal yang baru maupun dengan mengembangkan pusat pertumbuhan lokal yang telah ada, melalui pengembangan kawasan sentra produksi pangan, kawasan industri berbasis kompetensi inti industri daerah, dan juga dilakukan melalui pengembangan kawasan transmigrasi dengan skema Kota Terpadu Mandiri. Kawasan strategis ekonomi yang dibangun di berbagai wilayah potensial di Indonesia diharapkan dapat menggerakkan pertumbuhan ekonomi di wilayah sekitarnya, dan membentuk keterkaitan dengan daerah sekitarnya dalam suatu keterpaduan sistem ekonomi wilayah. ${ }^{28}$

Penataan ruang merupakan suatu tahapan dari proses pengembangan wilayah yang terdiri dari perencanaan, pemanfaatan dan pengendalian ruang. Dalam rangka mewujudkan masyarakat makmur yang bertempat tinggal di ruang yang nyaman dan lestari, penyelenggaraan pembangunan wilayah yang berbasis penataan ruang merupakan suatu keharusan. Upaya tersebut akan efektif dan efisien apabila prosesnya dilakukan secara terpadu dengan seluruh pelaku pembangunan di wilayah setempat. Hal tersebut sejalan dengan semangat yang tumbuh dalam era otonomi daerah yang mengedepankan Pemerintah Pusat sebagai fasilitator dengan mendorong peningkatan pelayanan publik dan pengembangan kreatifitas serta pelibatan masyarakat dan juga aparatur pemerintahan di daerah. Dengan demikian kebiasaan 'menginstruksikan' masyarakat untuk berperan serta dalam pembangunan, khususnya dalam pemanfaatan ruang, bisa dihindari bersama.

Penataan ruang merupakan proses perencanaan ruang, pemanfaatan ruang, dan pengendalian pemanfaatan ruang. Oleh karenanya dalam proses penataan ruang, tidak terbatas pada proses perencanaan saja. Tetapi, meliputi aspek pemanfaatan yang merupakan wujud operasional rencana tata ruang serta proses pengendalian pemanfaatan ruang. Proses pengendalian pemanfaatan

\footnotetext{
${ }^{28}$ Johara T.Jayadinata, Tata Guna Tanah dalam Perencanaan Pedesaan Perkotaan dan Wilayah, Penerbit ITB, 2007. h. 5
} 
memiliki mekanisme pengawasan dan penertiban terhadap pelaksanaan pembangunan agar sesuai dengan Rencana Tata Ruang Wilayah (RTRW) dan tujuan penataan ruang wilayah.

\section{Kesimpulan}

Berdasarkan hasil penelitian dan analisis yang dilakukan melalui pengkajian sebagaimana yang telah diuraikan dalam bab-bab sebelumnya, maka penelitian ini sampai pada kesimpulan sebagai berikut:

a. Penataan ruang terhadap alih fungsi lahanpada hakikatnya merupakanpenggunaan lahan yang disebabkan karena adanya perubahan rencana tata ruang wilayah yang di dukung dengan adanya kebijaksanaan arah pembangunan. Dengan adanya Kebijakan pembangunan tersebut, maka pembangunan yang dimaksud adalah pembangunan secara makro, utamanya pembangunan ekonomi masyarakat berbagai aktifitas pembangunan, mulai pembangunan industri, pembangunan perumahan, transportasi, perdagangan, perkebunan, pertanian, kelautan/maritim dan lain-lain. Aktifitas dan penyelenggaraan pembangunan beraneka ragam tersebut sudah tentu memerlukan lahan yang sangat luas.

b. Alih fungsi lahan terhadap pembangunan berkelanjutan ditujukan terhadapperencanaan yang berorientasi pada kepentingan jangka panjang. Perencanaan pembangunan berkelanjutan memerlukan pendekatan yang bersifat simultan antara tiga dimensi pokok dari pembangunan berkelanjutan, yaitu: (1). Keberlanjutan lingkungan dapat terjadi jika dalam segala aktivitasnya, manusia menjaga agar pemanfaatan sumberdaya alam masih di bawah daya dukung lingkungannya serta limbah yang dihasilkan dari pemanfaatan sumberdaya alam tersebut juga masih di bawah ambang batas. (2). Keberlanjutan pertumbuhan ekonomi dilakukan dengan 
mempertahankan kapital (sumberdaya alam) atau menjaga agar kapital tidak mengalami kemerosotan ketika kapital tersebut dimanfaatkan. (3). Keberlanjutan sistem sosial yang menekankan pada segi kualitas daripada aspek pertumbuhan yang bersifat kuantitas.

\section{Daftar Pustaka}

Effendy, Sumardja. 2004. Pembangunan Berkelanjutan: Tantangan dan Peluang. Jurnal Lingkungan dan Pembangunan.

Jayadinata, Johara. 2007. Tata Guna Tanah dalam Perencanaan Pedesaan Perkotaan dan Wilayah, Penerbit ITB.

Marzuki, Peter Mahmud. 2010. Penelitian Hukum. Jakarta:Kencana Prenada Media Group.

Nurlinda, Ida. 2009. Prinsip- Prinsip Pembaruan Agraria "Perspektif Hukum". Jakarta:Rajawali Press.

Rahmi, Dwita Hadi. 2003. Pengelolaan Sumberdaya dan Lingkungan. Yogyakarta:Gadjah Mada University Press. 


\section{Makalah dan Artikel}

Badan Pembinaan Hukum Nasional Kementerian Hukum dan Hak Asasi Manusia R.I., Laporan Akhir Tim Pengkajian Hukum Tentang Penegakan Hukum Penataan Ruang Dalam Kerangka Otonomo Daerah, Jakarta, 2014

https://agribisnis14.wordpress.com/.../alih-fungsi-lahan-pertanian/. Di akses pada tanggal 7 Juni 2017

https://agribisnis14.wordpress.com/.../alih-fungsi-lahan-pertanian/. Di akses pada tanggal 7 Juni 2017

https://www.google.co.id/?hl=en\&gws_rd=ssl\#hl=en\&q=implikasi+pengaturan+pe nataan+ruang+terhadap+alih+fungsi+lahan. Di akses pada tanggal 9 Juni 2017 